\title{
Pengolahan Limbah Jerami Padi dengan Limbah Jamu Menjadi Pupuk Organik Plus
}

\author{
Processing of Rice Straw Waste with Herbal Waste into Organic Fertilizer Plus \\ Catur Rini Sulistyaningsih \\ Universitas Veteran Bangun Nusantara Sukoharjo \\ caturrinisulistyaningsih@gmail.com
}

Riwayat Artikel: Dikirim 16 Juni 2019; Diterima 25 November 2019; Diterbitkan 30 November 2019

\begin{abstract}
Abstrak
Tujuan dari program ini ini adalah untuk meningkatkan pengetahuan dan ketrampilan khalayak sasaran tentang pengolahan jerami dengan limbah jamu secara praktis. Dengan kegiatan ini kelompok tani dihimbau dapat memanfaatkan limbah jerami yang melimpah dan kurang di daya gunakan sehingga dapat memenuhi kebutuhan pupuk organik dan kebutuhan unsur hara tanaman terpenuhi. Pengabdian pada masyarakat dilaksanakan mulai bulan Juli sampai Oktober 2011 di Kelurahan Gedong, Kecamatan / Kabupaten Karanganyar. Bentuk kegiatan pengabdian pada masyarakat yaitu memberi penyuluhan (ceramah dan tanya jawab) dan demonstrasi pembuatan pupuk jerami dengan limbah jamu. Sasaran kegiatan adalah kelompok tani padi sawah di Kelurahan Gedong, Kecamatan / Kabupaten Karanganyar. Kegiatan pengabdian kepada masyarakat yang telah dilakukan menyebabkan adanya peningkatan pengetahuan peserta tentang pembuatan pupuk organik dari jerami dengan limbah jamu sebesar 1,61\% dan peningkatan ketrampilan tentang pembuatan pupuk organik jerami dengan limbah jamu sebesar 3,80\%. Presentasi pemahaman materi meningkat menjadi 156, $57 \%$. Para peserta merasa puas karena dengan teknologi maju yaitu pengomposan dengan menggunakan limbah jamu menyebabkan jerami dapat difermentasi (terurai) lebih cepat dan praktis, sehingga pupuk organik dari jerami dapat segera dimanfaatkan pada periode tanam berikutnya.
\end{abstract}

Kata kunci: limbah jerami, limbah jamu, pupuk organik plus

\begin{abstract}
The purpose of this program is to increase the knowledge and skills of the target audience about processing straw with medicinal waste in a practical manner. With this activity, farmer groups are encouraged to take advantage of the abundant and underutilized straw waste so that they can meet the needs of organic fertilizer and plant nutrient needs are met. Community service is carried out from July to October 2011 in Gedong Village, Karanganyar District / District. The form of community service activities is providing counseling (lectures and questions and answers) and demonstration of making straw fertilizer with herbal medicine waste. The target activity is a group of rice farmers in Gedong Village, Karanganyar District / District. Community service activities that have been carried out have led to an increase in participant's knowledge about making organic fertilizer from straw with medicinal waste by $1.61 \%$ and increasing skills about making straw organic fertilizer with herbal medicine waste by $3.80 \%$. Presentation of understanding of the material increased to 156, 57\%. The participants were satisfied because with advanced technology that is composting using medicinal waste, straw can be fermented faster and more practically, so that organic fertilizer from straw can be used immediately in the next planting period.
\end{abstract}

Keywords: straw waste, herbal waste, organic fertilizer plus

\section{PENDAHULUAN}

Lokasi kelurahan Gedong secara administratif termasuk dalam wilayah Kecamatan Karanganyar Kabupaten Karanganyar, provinsi Jawa Tengah. Kelurahan Gedong yang terletak Kelurahan Gedong Kecamatan Karanganyar terletak di sebelah utara kota Karanganyar dengan luas wilayah 573.713,5 Hektar dengan jumlah penduduk Laki-laki sekitar 3.143 orang, perempuan sekitar 3.314 orang, sehingga total jumlah penduduk 6.457 orang, yang sebagian besar penduduknya adalah merupakan petani dan bahkan sebagian juga sebagai buruh tani (data statistik Kalurahan 
Gedong). Para petani ini tergabung dalam kelompok tani -kelompok tani yang masing-masing kelompok tani anggotanya bervariasi antara 10 sampai 20 petani. Kelompok Tani adalah kelompok masyarakat yang terikat secara non formal atas dasar keserasian dan kesamaan kondisi lingkungan (sosial, ekonomi, dan sumber daya) keakraban, kepentingan bersama dan saling percaya mempercayai serta disamping itu juga mempunyai pemimpin untuk mencapai tujuan bersama (Anonim, 1981). Kelompok tani yang ada di Kelurahan Gedong pada awalnya dibentuk dengan tujuan untuk memudahkan pendistribusian pupuk bersubsidi dari pemerintah, dan juga hingga kini masih eksis.

Berdasarkan keadaan pengairan yang ada, semua lahan sawah di Kelurahan Gedong sudah berpengairan secara teknis, sehingga para petani padi dapat panen ratarata 3 kali setiap tahun. Oleh karena itu lahan sawahnya tidak ada kesempatan bero atau mengganngur tidak ditanami. Dengan keadaan yang demikian ini berarti setiap habis panen selalu melimpah limbah jerami yang belum dimanfaatkan secara maksimal oleh warga, namun hanya sebagian kecil saja yang digunakan untuk pakan ternak khususnyab terenak sapi.

Ketersediaan jerami di Indonesia sangat melimpah terutama saat panen raya, hal ini dikarenakan hampir di setiap wilayah di Indonesia dapat di jumpai areal persawahan yang selain menghasilkan gabah juga menghasilkan jerami.

Pada beberapa tempat, jerami padi bahkan menjadi limbah yang tidak terpakai. Padahal, bahan organik jerami padi sangat bagus digunakan sebagai media tanam baru. Jerami adalah hasil samping usaha pertanian berupa tangkai dan batang tanaman serealia yang telah kering, setelah biji-bijiannya dipisahkan. Massa jerami kurang lebih setara dengan massa biji-bijian yang dipanen. Jerami memiliki banyak fungsi.

Di beberapa tempat lainnya, jerami padi dimanfaatkan sebagai pakan ternak sapi. Selain itu, jerami padi juga mudah didapatkan. Selain itu, sapi yang mengonsumsi jerami padi akan menghasilkan pupuk kandang dari kotorannya. Kotoran tersebut, nantinya akan dikelola menjadi pupuk organik dan akan bermanfaat bagi tanaman dan tentunya menghasilkan nilai jual. Sebenarnya para petani menyadari bahwa jerami padi yang melimpah setiap tahun dapat dimanfaatkan untuk digunakan atau diolah sebagai pupuk dengan menggunakan atau memanfaatkan limbah jamu, namun karena keterbatasan waktu dan tenaga dalam menangani limbah tersebut sering kali jerami hanya dibiarkan teronggok. Hal ini dikarenakan pada umumnya sehabis panen, petani berfokus segera mengolah tanah untuk tanam periode berikutnya, sehingga hampir tidak ada waktu menangani sisa jerami secara tradisional yang biasanya memerlukan waktu yang relatif lama yaitu kurang lebih 2 sampai 3 bulan (Anonim, 1982). Dengan pengolahan jerami secara tradisional ini juga menyebabkan adanya bau busuk dan lalat yang berlebihan sehingga mengganggu lingkungan. Padahal sisa jerami sangat potensial sebagai pupuk organik yang sangat baik untuk memperbaiki struktur tanah dan meningkatkan kesuburan tanah (Lingga dan Marsono, 2002).

Dalam melaksanakan budidaya ada prinsip yang merupakan kewajiban kita (khususnya petani) untuk selalu mempertahankan kesuburan tanah dengan cara mengembalikan zat-zat yang diambil dari dalm tanah, artinya kita hanya mengambil zat-zat yang dapat dikonsumsi saja, maka limbahnya harus dikembalikan ke tanah (Soedjanto, 1977). Indonesia, negeri subur, sumber air melimpah, kaya akan tambang, minyak, mineral maupun gas bumi dan memiliki sumber hayati terbesar di dunia.

Jamu adalah sebutan untuk obat tradisional dari Indonesia. Bahan baku jamu yang sekitar 95 persen tersebut, berasal dari bumi kita, ditanam oleh petani di berbagai pelosok tanah air. Belakangan populer dengan sebutan herba atau herbal. Jamu 
dibuat dari bahan-bahan alami, berupa bagian dari tumbuhan seperti rimpang (akarakaran), daun-daunan, kulit batang, dan buah. Ada juga menggunakan bahan dari tubuh hewan, seperti empedu kambing, empedu ular, atau tangkur buaya. Seringkali kuning telur ayam kampung juga dipergunakan untuk tambahan campuran pada jamu gendong. Agar pembuangan limbah tidak merusak lingkungan, maka perlu adanya suatu proses tambahan.

Jamu ternyata memiliki banyak manfaat. Selain untuk kesehatan, limbahnya juga bisa bermanfaat untuk lingkungan. Meningkatnya jumlah industri jamu berpengaruh terhadap kenaikan limbah yang dihasilkan, yang biasanya secara normal diproses dalam bak anaerobik menggunakan proses kimia dan biologi. Namun proses tersebut tidak ekonomis dan karena itu metode alternatif menggunakan sumber alami sangat dibutuhkan.

Limbah jamu dimanfaatkan sebagai pengurai bagi sisa jerami. Sebelum mengalami proses peruraian/dekomposisi maka jerami tersebut tidak berguna bagi tanaman, karena ratio $\mathrm{C} / \mathrm{N}$ jerami masih tinggi ( $>30$ ). Sehingga tidak bisa tersedia bagi tanaman. Bahan organik yang dapat diserap tanaman jika ratio $\mathrm{C} / \mathrm{N}$ nya mendekati $\mathrm{C} / \mathrm{N}$ tanah yaitu $10-12$, untuk itu maka jerami harus diproses dahulu sehinggga menjadi pupuk organik / kompos (Sutejo, M.M, 1995). Manfaat pupuk organik sangat besar baik bagi tanaman maupun tanah antara lain ; dapat meningkatkan kesuburan tanah ; memperbaiki struktur tanah ; meningkatkan kemampuan tanah menyerap air ; meningkatkan KPK tanah (Kapasitas Pertukaran Kaiton tanah ) ; meningkatkan daya ikat tanah terhadap zat hara (Suharno, 1990). Oleh karena itu di wilayah ini perlu dilakukan penyuluhan dan pelatihan penanganan sisa jerami padi dengan menggunakan limbah jamu yang mana dapat dilakukan secara praktis dan dalam waktu yang relatif singkat dapat dimanfaatkan petani.
Berdasarkan pembicaraan yang telah dilakukan antara tim penyusul pengabdian dengan mitra bahwa mitra akan mendukung sepenuhnya dan juga bekerja sama dengan tim pengusul pengabdian pada masyarakat dari Universitas Veteran Bangun Nusantara Sukoharjo dalam menangani sisa jerami dengan limbah jamu menjadi pupuk organik plus di Kelurahan Gedong, Kecamatan Karanganyar Kabupaten Karanganyar untuk diolah menjadi pupuk organik plus supaya segera bisa dimanfaatkan oleh para petani.

Berbagai permasalahan yang dihadapi mitra yaitu antara lain petani padi sawah yang tergabung dalam kelompok tani di kelurahan Gedong kecamatan Karanganyar kabupaten Karanganyar yang teridentifikasi sebagai berikut :

a. Pengetahuan Para anggota kelompok tani dalam mengolah limbah jerami dengan limbah jamu menjadi pupuk organic plus dengan teknologi pembuatan pupuk yang cepat dan praktis masih minim.

b. Demikian juga, ketrampilan dalam membuat pupuk organik plus dari limbah jamu dengan teknologi pembuatan pupuk organik yang cepat dan juga praktis belum dimiliki.

c. Adanya gangguan dalam pengolahan jerami secara tradisional (pengomposan tradisional ) yang sering dikeluhkan warga sekitar yaitu adanya bau busuk dan lalat yang berlebihan (Anonim, $1980)$.

Tujuan yang hendak akan dicapai dalam kegiatan ini adalah untuk meningkatkan pengetahuan dan ketrampilan khalayak sasaran tentang pembutan pupuk organik plus yang berasal dari limbah jerami dengan limbah jamu secara praktis. Berbagai hasil penelitian menunjukkan, bahwa pemanfaatan pupuk organik pada lahan pertanian berdampak positif terhadap ketersedian hara, pertumbuhan dan produksi tanaman. Pupuk organik berperan dalam meningkatkan kesuburan fisik, kimia 
dan biologi tanah serta mengefisienkan penggunaan pupuk anorganik.

Pupuk organik adalah pupuk yang tersusun dari materi makhluk hidup, seperti pelapukan sisa -sisa tanaman, hewan, dan manusia.[1] Pupuk organik dapat berbentuk padat atau cair yang digunakan untuk memperbaiki sifat fisik, kimia, dan biologi tanah.[2] Pupuk organik mengandung banyak bahan organik daripada kadar haranya.[2] Sumber bahan organik dapat berupa kompos, pupuk hijau, pupuk kandang, sisa panen (jerami, brangkasan, tongkol jagung, bagas tebu, dan sabut kelapa), limbah ternak, limbah industri yang menggunakan bahan pertanian, dan limbah kota (sampah). Pupuk organik dapat berbentuk padat atau cair yang digunakan untuk memperbaiki sifat fisik, kimia, dan biologi tanah. Pupuk organik mengandung banyak bahan organik daripada kadar haranya. Jenis-jenis Pupuk Organik Hasil Perkembangan Teknologi Pupuk hijau. Pupuk hijau berasal dari pelapukan tanaman, baik tanaman sisa panen maupun tanaman yang sengaja ditanam untuk diambil hijauannya. Pupuk kandang. Pupuk kandang berasal dari kotoran hewan seperti unggas, sapi, kerbau, dan kambing. Pupuk kompos. Pupuk hayati organik. Jenis-jenis Pupuk Organik Hasil Perkembangan Teknologi. Pupuk hijau. Pupuk hijau berasal dari pelapukan tanaman, baik tanaman sisa panen maupun tanaman yang sengaja ditanam untuk diambil hijauannya. Pupuk kandang. Pupuk kandang berasal dari kotoran hewan seperti unggas, sapi, kerbau, dan kambing. Pupuk kompos. Pupuk hayati organik.

Pupuk Bio Organik Plus adalah Pupuk Organik Cair yang dihasilkan dari proses Bioteknologi bahan bahan organik pilihan ramah lingkungan dan sangat bermanfaat untuk memaksimalkan hasil budidaya tanaman. Diperkaya dengan konsorsium mikrobia-mikrobia yang dipilih secara khusus dan selektif dari mikrobia monokultur. Adapun kelebihan dengan menggunakan mikrobia monokultur adalah:
1. Keunggulan dan manfaat masingmasing mikrobia sudah teruji

2. Mikrobia yang tumbuh adalah mikrobia pilihan yang benar-benar diinokulasikan sehingga dapat bersinergi dan saling mendukung

3. Hasil-hasil metabolisme mikrobia yang berupa asam-asam amino, zat pengatur tumbuh, antibiotic, enzyme dan vitamin lebih maksimal.

4. Setelah diaplikasikan ke lahan, jumlah dan aktivitas kerja mikrobia menjadi lebih dominan.

5. Aroma berbau harum khas fermentasi

6. Aplikasi mudah hanya dicampur dengan air

Dengan mikrobia-mikrobia unggul tersebut maka penyerapan unsur hara (pupuk kimia) oleh tanaman akan lebih maksimal sekaligus meningkatkan produktifitas lahan.

\section{METODE}

Untuk mengatasi berbagai permasalahan yang dihadapi mitra yaitu direalisasikan dengan kegiatan sebagai berikut: 1). Memberi penyuluhan tentang manfaat pupuk organic plus dan teknik pembuatan pupuk organik plus dari limbah jerami dengan limbah jamu secara cepat dan praktis. 2). Memberi percontohan atau demonstrasi cara pembuatan pupuk organik plus secara praktis dari limbah jerami dengan limbah jamu. 3) Pendampingan pembuatan pupuk organik plus secara praktis dan cepat, dari limbah jerami dengan limbah jamu. Dengan teknologi tersebut dapat mengurangi gangguan pencemaran lingkungan, seperti bau tidak sedap akibat pembusukan jerami dan berdatangannya lalat akibat pengomposan tradisional.

Metode yang digunakan dalam pelaksanaan pengabdian kepada masyarakat ini adalah:

a. Pemberian materi atau teori dengan cara penyuluhan tentang pengertian, manfaat dan cara pembuatan pupuk organik plus. 
b. Demonstrasi untuk percontohan cara pembuatan pupuk organik plus dari limbah jerami padi dengan limbah jamu secara cepat dan praktis.

c. Dilakukan evaluasi sebelum dan sesudah diberi teori maupun demonstrasi untuk mengetahui adanya peningkatan pengetahuan kelompok tani tentang pupuk organik plus.

Langkah-langkah Pengolahan limbah jerami padi dengan limbah jamu menjadi pupuk organik plus.

1. Limbah jerami seberat $500 \mathrm{~kg}$ dikumpulkan pada suatu tempat yang teduh dan tidak tergenang air.

2. Jerami ditumpuk dengan ketinggian maksimum 1 ataupun 1.5 meter, panjang dan lebar menyesuaikan tempat (2 sampai $3 \mathrm{~m}$ ), biasanya dipinggir sawah di bawah pohon.

3. Setiap ketebalan antara 25 sampai $30 \mathrm{~cm}$ tumpukan jerami di semprot dengan cairan produk sampingan dari jamu dengan kadar $2 \%$ sampai merata dan diulang 4 kali tumpukan jerami setinggi satu meter. Fungsi dari produk sampingan jamu tersebut berfungsi sebagai pengurai jerami, produk sampingan tersebut mengandung bakteri pengurai bahan organik. Akan lebih baik bila tumpukan jerami tersebut diberi alas dari plastik $2 \times 11 \mathrm{~m}$, serta diberi sedikit pupuk kandang dan sedikit urea, supaya perombakan berjalan lebih cepat.

4. Setelah selesai, tumpukan jerami ditutup dengan terpal maupun plastic ataupun karung secara rapat.

5. Tumpukan tersebut diaduk dan disemprot cairan pengurai organik dengan interval waktu kurang lebih 5 sampai 7 hari sekali.

6. Setelah kurang lebih 2 sampai 3 minggu tumpukan dibongkar dan apabila jerami telah menjadi kompos, yang ditandai jerami sudah tidak berbentuk seperti aslinya, maka pupuk tersebut sudah siap digunakan.

\section{HASIL DAN PEMBAHASAN}

\section{Hasil}

Pemberian materi teori dengan cara memberi penyuluhan tentang pengertian pupuk organik plus manfaat pupuk organik plus dan cara maupun teknik pembuatan pupuk organik plus secara cepat dan praktis, di kelurahan Gedong, Kecamatan Karanganyar Kabupaten Karanganyar, ditujukan untuk rneningkatkan pengetahuan kelompok tani tentang pentingnya menjaga dan meningkatkan k.esuburan tanah, dengan cara mengembalikan sebagian hasil panen ke tanah sawah sehingga produktivitas tanah tetap baik.

Materi yang diberikan meliputi:

1. Pengertian tentang pupuk organik plus.

Pupuk organik (pupuk alam) adalah pupuk yang berasal dari sisa-sisa tanaman, hewan bahkan juga manusia yang pada urnumnya sudah mengalami dekomposisi.

Yang termasuk pupuk organik antara lain:

a. Pupuk kandang: berasal dari sisasisa kotoran hewan.

Pupuk kandang ialah olahan kotoran hewan, biasanya ternak, yang diberikan pada lahan pertanian untuk memperbaiki kesuburan dan struktur tanah. Pupuk kandang adalah pupuk organik, sebagaimana kompos dan pupuk hijau. Pupuk kandang selain digunakan untuk menyediakan unsur hara bagi tanaman, juga berguna untuk memperbaiki sifat fisik, kimia dan biologi tanah. Komposisi unsur hara yang terdapat pada pupuk ini tergantung pada asal jenis hewannya. Umur, alas kandang dan pakan yang diberikan pada hewan juga berpengaruh pada komposisi pupuk organik kandang yang dihasilkan. Masing-masing jenis hewan menghasilkan kotoran yang mengandung unsur hara unik. Namun secara general kotoran 
hewan mengandung unsur hara makro seperti nitrogen $(\mathrm{N})$, posfor $(\mathrm{P})$, kalium $(\mathrm{K})$, kalsium (Ca), magnesium $(\mathrm{Mg})$ dan belerang $(\mathrm{S})$. Jika dibandingkan dengan pupuk kimia, kadar kandungan unsur hara dalam pupuk kandang jauh lebih kecil. Oleh sebab itu, perlu pemakaian pupuk kandang yang banyak untuk menyamai pemberian pupuk kimia. Pupuk kandang bermanfaat untuk menyediakan unsur hara makro dan mikro dan mempunyai daya ikat ion yang tinggi sehingga akan mengefektifkan bahan - bahan anorganik di dalam tanah, termasuk pupuk anorganik. Selain itu, pupuk kandang bisa memperbaiki struktur tanah, sehingga pertumbuhan tanaman bisa optimal. Pupuk kandang yang telah siap diaplikasikan memiliki ciri bersuhu dingin, remah, wujud aslinya tidak tampak, dan baunya telah berkurang. Jika belum memiliki ciri-ciri tersebut, pupuk belum siap digunakan.

Zat hara yang dikandung pupuk kandang tergantung dari sumber kotoran bahan bakunya. Pupuk kandang ternak besar kaya akan nitrogen, dan mineral logam, seperti magnesium, kalium, dan kalsium. Pupuk kandang ayam memiliki kandungan fosfor lebih tinggi. Namun, manfaat utama pupuk kandang adalah mempertahankan struktur fisik tanah sehingga akar dapat tumbuh secara baik. Penggunaan pupuk yang belum matang akan menghambat pertumbuhan tanaman, bahkan bisa mematikan tanaman. Penggunaan pupuk kandang yang baik adalah dengan cara dibenamkan, sehingga penguapan unsur hara dapat berkurang. Penggunaan pupuk kandang yang berbentuk cair paling baik dilakukan setelah tanaman tumbuh, sehingga unsur hara yang terdapat dalam pupuk kandang cair ini akan cepat diserap oleh tanaman.

Sebagaimana jenis pupuk organik lainnya, seperti pupuk hijau dan pupuk kompos, pupuk kandang memiliki sejumlah kelebihan seperti memperbaiki struktur tanah, tanah lebih ringan sehingga mudah diolah dan mudah ditembus akar, mengandung sejumlah mikroba yang berguna untuk dekomposisi bahan organik. Kelemahannya adalah pupuk kandang tidak steril dan bentuknya kamba (bulky) karena mengandung biji-bijian berbagai bibit penyakit/parasit tanaman dan gulma.

Tumpukan kotoran hewan dapat menghasilkan panas selama proses dekomposisi sehingga dapat terbakar secara spontan jika ditumpuk dalam tumpukan yang besar. Ketika kotoran hewan sudah terbakar, udara akan tercemar, menimbulkan bau tidak sedap.

b. Pupuk hijau: berasal dari sisa-sisa tanaman.

Pupuk hijau adalah pupuk yang berasal dari dekomposisi sisa tanaman. Dalam dunia pertanian, pupuk hijau kembali dilirik sebagai sumber bahan organik potensial mengingat lahan pertanian dewasa ini telah mengalami degradasi. Hal ini disebabkan oleh hilangnya bahan organik dalam tanah karena penggunaan pupuk kimia secara massif.

Berdasarkan laporan BBSDLP (2006), kadar bahan organik pada lahan-lahan pertanian di Indonesia kurang dari $1 \%$. Padahal lahan pertanian yang baik idealnya memiliki kandungan bahan organik $3-5 \%$.

Sama seperti jenis pupuk organik lainnya, pupuk hijau memilki kemampauan untuk 
memperbaiki sifat fisik, kimia dan biologi tanah. Penggunaan pupuk hijau dalam pertanian, membantu lingkungan mempertahankan siklus ekologinya. Karena pada saat panen, sebagian biomassa tetap berada di lahan dan dipergunakan lagi untuk musim tanam berikutnya. Sehingga asupan luar dalam produksi pertanian bisa ditekan serendah mungkin. Secara umum, hampir semua jenis tanaman bisa dijadikan sumber pupuk hijau. Namun sebaiknya gunakan tanaman yang memiliki kandungan humus total tinggi, kandungan nitrogen tinggi dan rasio $\mathrm{C} / \mathrm{N}$ (nisbah karbon terhadap nitrogen) rendah. Pakar agroekosistem Cheryl A Palm, menerangkan bahwa pupuk hijau yang berkualitas tinggi memiliki kandungan nitrogennya lebih dari $2,5 \%$, kandungan lignin kurang dari $15 \%$ dan kandungan polifenol kurang dari 4\%. Tanaman dengan karakteristik seperti itu akan mudah terurai di dalam tanah dan unsur nitrogennya bisa diserap tanaman dengan mudah. Apabila kandungan lignin dan polifenol tinggi akan membutuhkan lebih banyak nitrogen dalam proses pelapukannya. Sehingga berpotensi untuk bersaing dengan tanaman inti.

Berikut ini beberapa jenis tanaman yang biasa dijadikan sumber pupuk hijau.

- Sisa tanaman produksi

- Tanaman pagar

- Tanaman penutup tanah

- Tanaman liar

c. Kompos: berasal dari jerami, saimpah kota, limbah pabrik, dll.

Hasil dekomposisi atau fermentasi bahan-bahan organik seperti sisa hewan, tanaman, dan limbah organik lainnya dapat menghasilkan kompos yang dimanfaatkan untuk memperbaiki struktur tanah, memperbaiki

kehidupan mikroorganisme dalam tanah, menambah daya ikat air terhadap tanah, dan memperbaiki sifat-sifat tanah lainnya.

Pupuk kompos mengandung unsur-unsur hara mineral yang baik untuk tanaman serta meningkatkan bahan organik dalam tanah. Pembuatan pupuk ini pun dapat dibuat sendiri dengan memanfaatkan bahan-bahan organik yang mudah didapatkan dengan harga pembuatan yang relatif murah.

Pemanfaatan limbah-limbah pertanian atau sampah organik untuk bahan baku pembuatan pupuk ini sangat menguntungkan dengan tidak adanya modal yang besar untuk pembuatannya.

Kompos dapat dibedakan menjadi beberapa jenis. Berbagai jenis kompos yaitu di antaranya kompos cacing, bagase, dan bokashi.

Kompos sebagai salah satu pupuk organik sangat baik dan bermanfaat untuk segala jenis tanaman. Pupuk ini digunakan untuk tanaman pangan, tanaman perkebunan, tanaman pertanian, dan bahkan tanaman hias. Hanya dengan menaburkannya di permukaan tanah, maka sifat-sifat tanah yang baik dapat dipertahankan bahkan ditingkatkan lagi. Apalagi untuk kondisi tanah hasil pembukaan lahan baru, biasanya pada area tersebut kesuburan tanah menurun karena pembukaan lahan identik dengan pembakaran atau penghilangan top soil. Oleh karena itu, kesuburan tanah perlu dikembalikan dan dipercepat dengan ditambahkan pupuk. Manfaat kompos dapat dilihat dari aspek ekonomi, aspek lingkungan, serta aspek bagi tanah dan 
tumbuhan. Dari aspek ekonomi, pupuk ini memanfaatkan bahanbahan organik yang berasal dari limbah-limbah pertanian yang mudah didapatkan di sekitar kita, sehingga pupuk ini tidak memerlukan biaya yang besar dalam pembuatannya. Manfaat pupuk ini dari aspek lingkungan yaitu mengurangi pencemaran lingkungan. Pencemaran lingkungan berhubungan erat dengan sampah yang merupakan sumber pencemaran lingkungan.

Dengan banyaknya sampah yang berserakan baik di sungai maupun sampah yang tercecer dan masuk ke selokan akan mengakibatkan penyumbatan di selokan dan dapat menimbulkan banjir.

Banyaknya jumlah sampah akan mengakibatkan permasalahan baru yaitu tempat pembuangan akhir sampah yang harus diperbanyak pula.

Tempat yang dijadikan pembuangan akhir sampah ini akan menjadi kumuh dan kotor jika pengolahan sampah tidak diatasi dengan benar.

Tempat tersebut juga akan menimbulkan banyak penyakit karena sebagai sarang bertumbuhkembangnya organisme yang membahayakan bagi kesehatan manusia dan semakin menurunkan daya dukung lingkungan sebagai tempat pembuangan sampah. Manfaat bagi tanah dan tumbuhan yaitu meningkatkan kesuburan tanah serta menyediakan unsurunsur hara mineral memadai dan seimbang yang bisa diserap oleh tanaman.

Produtivitas dari tanaman akan berkurang jika tanaman kekurangan unsur hara dan mineral, terutama jika tanaman tersebut tumbuh pada tanah yang bersifat terlalu asam maupun terlalu basa.

Manfaat lainnya yaitu memperbaiki struktur, drainase dan tata udara dalam tanah, memperbesar daya ikat air terhadap tanah, daya ikat tanah terhadap unsur hara, membantu dalam proses pelapukan mineral, menjadi sumber bahan makanan bagi mikroorganisme, dan menurunkan aktivitas mikroba yang merugikan.

Bahan organik berpengaruh terhadap sifat fisik, biologi, dan kimia tanah. Peran bahan organik terhadap sifat fisik tanah yaitu memperbaiki aerasi tanah, merangsang granulasi tanah, dan meningkatkan daya ikat air.Peran bahan organik terhadap sifat biologi tanah yaitu aktivitas mikroorganisme yang berperan dalam fiksasi nitrogen dan transfer hara tertentu akan meningkat. Peran bahan organik terhadap sifat kimia tanah yaitu kapasitas tukar kation meningkat sehingga dapat mempengaruhi serapan unsur hara tanaman. Bahan organik yang umum dimanfaatkan untuk pembuatan pupuk ini berasal dari limbah-limbah pertanian meliputi:

- limbah dan residu tanaman,

- limbah dan residu ternak,

- pupuk hijau,

- penambat nitrogen seperti jerami,

- sekam padi,

- gulma,

- semua bagian vegetatif tumbuhan,

- kotoran padat hewan,

- limbah ternak cair,

- sisa pakan ternak,

- mikroorganisme, serta

- mikoriza dan rhizobium.

Bahan organik lainnya yang dapat dikomposkan adalah buah- 
buahan, sayuran, limbah kebun termasuk rumput, dan dedaunan serta limbah dapur. Selain itu, bahan lainnya yaitu bahan selulosa yang merupakan bahan yang mempunyai struktur seluler yang sebagian besar terdiri dari lignin dan selulosa yang mempunyai kadar air yang relatif rendah. Contoh bahan selulosa adalah kertas, sisipan kayu, daun kering, jerami padi, dan kulit pohon. Limbah protein yang termasuk ke dalam limbah dan residu ternak sangat bagus sebagai bahan pembuatan kompos karena banyak mengandung protein yang mempunyai kandungan nutrisi yang baik bagi pertumbuhan tanaman.

d. Sisa-sisa hewan dan bahkan manusia

\section{a. Manfaat Pupuk Organik Plus}

Bahan organik yang telah terdekomposisi sehingga menjadi pupuk organik bermanfaat :

- Bahan organik memperbesar daya ikat tanah yang berpasir, sehingga struktur tanah dapat diperbaiki sehingga tidak mudah ambyar.

- Bahan organik dapat rnemperbaiki struktur tanah berlempung, sehingga tanah yang tadinya berat dengan penambahan bahan organik akan menjadi lebih ringan pengolahannya.

- Bahan organik dalam tanah, akan mempertinggi kernampuan penyerapan air, sehingga tanah dapat lebih banyak menyediakan air bagi tanaman.

- Bahan organik dalam tanah dapat memperbaiki drainase dan tata udara tanah, terutama pada tanah berat, dengan tata udara yang baik dan kandungan air yang cukup tinggi maka suhu tanah akan stabil.

- Bahan organik dapat meningkatkan pengaruh pemupukan dari pupuk buatan.
- Bahan organik mempertinggi daya ikat tanah terhadap zat hara, sehingga tidak mudah larut oleh air pengairan maupun air hujan.

2. Cara pembuatan pupuk organik dari limbah jerami secara prakfis.

a. Limbah jerami dikumpulkan pada suatu tempat yang teduh dan tidak tergenang air.

b. Dibuat tumpukan jerami maksimum tinggi 1 sampai $1,5 \mathrm{~m}$, panjang dan lebar menyesuaikan tempat ( 2 sampai $3 \mathrm{~m}$ ), biasanya di pinggiran sawah di bawah pohon.

c. Dalam membuat tumpukan jerami tersebut setiap tebal 25 sampai 30 $\mathrm{cm}$ (sebagai satu lapisan), jerami tersebut disemprot dengan limbah jamu dengan kadar $2 \%$ sampai merata, demikian diulang sampai tumpukan setinggi lebih kurang satu meter. Fungsi limbah jamu yaitu mempercepat proses dekomposisi atau penguraian jerami, karena dalam limbah jamu terkandung bakteri pengurai bahan organik.

d. Setelah selesai, tumpukan jerami tersebut ditutup dengan terpal plastik maupun karung secara rapat.

e. Kurang lebih 5 sampai 7 hari sekali, tumpukan tersebut diaduk supaya proses terjadinya dekomposisi jerami merata dan disemprot limbah jamu sekali lagi.

f. Setelah 2 sampai 3 minggu tumpukan dibongkar dan apabila jerami telah menjadi kompos yang ditandai jerami sudah tidak tampak bentuk aslinya maka pupuk organik tersebut siap digunakan.

Limbah jamu merupakan starter yang mengandung bakteri pengurai bahan organik, sehingga dapat mempercepat proses dekomposisi bahan organik. Hasil kegiatan Pengabdian dari demonstrasi cara pembuatan pupuk organik plus dari limbah jerami dengan limbah jamu yang dilakukan di Kelurahan Gedong, Kecamatan 
Karanganyar Kabupaten Karanganyar adalah sebagai berikut:

Hasil evaluasi tentang Pembuatan pupuk organik plus dari limbah jerami padi dan limbah jamu (kompos terhadap tingkat pengetahuan dan ketrampilan para peserta yang dapat dilihat pada tabel 1.)

Tabel 1.

Rata-rata Tingkat Pemahaman peserta Tentang Pembuatan Pupuk Organik plus dari Limbah Jerami Padi dengan limbah jamu.

\begin{tabular}{|c|c|c|c|c|}
\hline \multirow[t]{3}{*}{ No } & \multirow{3}{*}{ Nama } & \multicolumn{3}{|c|}{ Rerata Tingkat Pemahaman } \\
\hline & & Sebelum & Sesudah & Persentase \\
\hline & & Pelatihan & Pelatihan & Peningkatan \\
\hline$(1)$ & (2) & (3) & (4) & $(5)$ \\
\hline 1 & Surat & 1,85 & 3,90 & 110,81 \\
\hline 2 & Pardi & 1,30 & 3,85 & 196,15 \\
\hline 3 & Saimin & 1,60 & 3,50 & 118,75 \\
\hline 4 & Pariyo & 1,50 & 3,75 & 150,00 \\
\hline 5 & Sariman & 1,35 & 3,50 & 159,26 \\
\hline 6 & Suyaman & 1,25 & 3,75 & 200,00 \\
\hline 7 & Tarman & 2,00 & 4,00 & 100,00 \\
\hline 8 & Sutarno & 1,45 & 3,85 & 165,52 \\
\hline 9 & Midin & 1,75 & 3,90 & 122,86 \\
\hline 10 & Remin & 2,00 & 4,00 & 100,00 \\
\hline & Rerata & 1,61 & 3,80 & 156,57 \\
\hline
\end{tabular}

Skor $4=$ sangat paham

Skor $3=$ paham

Skor $2=$ sedikit paham

Skor 1 = tidak paham

\section{Pembahasan}

Kegiatan Pengabdian Kepada Masyarakat dalam bentuk penyuluhan dan demonstrasi atau percontohan tentang pembuatan pupuk organik plus dari limbah jerami dengan limbah jamu di Kelurahan Gedong Kecamatan Karanganyar Kabupaten Karanganyar membawa semangat baru bagi para peserta khususnya petani. Hal ini terlihat dari antusias para peserta dalam mengikuti penyuluhan dan demonstrasi hingga selesai.

Keberhasilan ini tidak lepas dari adanya dukungan warga masyarakat GAPOKTAN di Kelurahan Gedong Kecamatan Karanganyar Kabupaten Karanganyar. Selain itu keingintahuan peserta tentang pengolahan jerami dengan limbah jamu menjadi pupuk organik plus sangat besar. Pengetahuan tentang pembuatan pupuk tersebut belum pernah diterima oleh peserta, sehingga mereka antuasia sekali dalam mengikuti kegiatan kegiatan pelatihan. Di desa Gedong dan sekitarnya bahan baku jerami mudah diperoleh.

Faktor penghambat dari kegiatan ini relatif kecil, dari 12 wakil gapoktan yang diundang 10 wakil hadir mengikuti pelatihan, sisanya yang 2 orang tidak dapat hadir karena alasan kesehatan.

Para peserta merasa senang karena dengan teknologi maju yaitu pengomposan menggunakan limbah jamu, ternyata limbah jerami dapat diproses lebih cepat dan praktis. Dengan proses fermentasi yang singkat ini maka pupuk organik dari limbah jerami dapat lebih cepat tersedia dan bisa segera digunakan di lahan masing-masing petani.

Dari hasil evaluasi tentang pembuatan pupuk organik dari limbah jerami padi terhadap tingkat pengetahuan dan ketrampilan para peserta yaitu dapat dijelaskan dari tabel 1. Hasil pretest menunjukkan bahwa pemahaman peserta sebelum pelatihan masih kurang paham tentang materi dengan rerata nilai 1,61 . dan setelah melaksanakan pelatihan rerata nilai post test 3,80\% ini berarti pemahaman peserta terhadap materi yang diberikan mengalami peningkatan sebesar 156, 57\% $\mathrm{Hal}$ ini menunjukkan bahwa kegiatan pengabdian kepada masyarakat berhasil meningkatkan pengetahuan dan ketrampilan peserta dalam pengolahan jerami dengan limbah jamu menjadi pupuk organik plus. Hal ini juga menunjukkan bahwa peserta dalam mengikuti penyuluhan dan pelatihan sangat antusias ingin menambah pengetahuan tentang cara pembuatan pupuk organik plus dari limbah jerami dengan limbah jamu secara praktis.

\section{KESIMPULAN}

Kesimpulan yang ditarik dari program ini antara lain: (1) Dengan adanya penyuluhan maka kelompok tani di Kelurahan Gedong, Kecamatan / Kabupaten Karanganyar, meningkat pengetahuannya tentang pupuk organik plus. Berdasar tabel 1. terjadi peningkatan 1,61\%. (2) Setelah diadakan 
demonstrasi cara pembuatan pupuk organik plus dari limbah jerami dengan limbah jamu secara praktis, maka ketrampilan peserta pelatihan meningkat $3,80 \%$.

\section{Saran}

Ada beberapa saran yang dapat diberikan terkait program ini antara lain: (1) Peserta pengabdian diharapkan menyebar luaskan informasi pengetahuan yang diperoleh kepada peserta yang tidak hadir . (2) Masyarakat mau menyampaikan permasalahan yang berkaitan dengan kegiatan pengabdian kepada masyarakat kepada Fakultas Pertanian Univet Bantara Sukoharjo, sehingga komunikasi terus berlangsung. (3) Perlu dilakukan kegiatan serupa di wilayah lain, sehingga masyarakat tani pada umumnya dapat memahami dan mengaplikasikan pembuatan pupuk organik plus di lapangan.

\section{DAFTAR PUSTAKA}

Anonim. (1980). Teknik Pengolahan Kompos. Departemen Pendidikan Dan Kebudayaan, Jakarta

Departemen Pertanian. (1981). Capita Selekta. Pengembangan Dan Pembinaan Kelompok Tani Dalam Intensifikasi Tanaman Pangan. Jakarta: Departemen Pertanian

Departemen Pendidikan, Dan Kebudayaan. (1982). Dasar-Dasar Pembuatan Kompos. Jakarta: Departemen Pendidikan, Dan Kebudayaan

Lingga Dan Marsono. (2002). Petunjuk Penggunaan Pupuk. Jakarta: Panebar Swadaya

Soedjanto. (1977). Pupuk Kandang, Pupuk Hijau Dan Pupuk Kompos. Jakarta: Bumi Restu.

Sukarno. (1990). Ilmu Kesuburan Tanab dan Pemupukan Buku II: bagian Pemupukan

Buku Pegangan Kuliah Fakultas Pertanian Universitas Sebelas Maret. Surakarta: Sebelas Maret University Press.

Sutejo. (1995). Pupuk dan Cara Pemupukan. Jakarta: Rineka Cipta 